\title{
DIAGNOSTICS BY FINANCIAL REGULATORS OF FINANCIAL INSTITUTIONS PREPAREDNESS TO THE IMPLEMENTATION OF ECONOMIC SECURITY MANAGEMENT
}

\author{
Nataliia Zachosova', Nataliia Babina²
}

\begin{abstract}
In the conditions of the financial system destabilization in Ukraine, caused by such negative phenomena as military actions in the East, the economic downturn, political and financial crises, population disappointment in the institution of power and loss of the people's confidence in power structures and so on, market mechanisms are not able to ensure the restoration of the national financial market and to encourage its professional participants to use mechanisms of protection their own assets and the assets of their clients from external and internal threats actively. State interference in the functioning of financial institutions is necessary, especially for those of their types, whose bankruptcy may have fatal consequences for the welfare of the population and cause the liquidation of economic entities of the domestic economy. Among them are: banks, insurance companies, credit unions, and other institutions of credit co-operation, investment companies, in particular, joint investment institutions (unit and corporate investment funds), non-state pension funds, leasing, factoring, and other financial companies, pawns, etc. Therefore, it is expedient to consider the possibility of the influence of state regulators in financial services markets on the state of their participants' economic security. However, the study of the realities of the financial market of Ukraine development has made it possible to assert that for a number of financial institutions, the concept of economic security is something abstract, and the understanding by their top management the importance of economic security management, taking into account the negative market trends, is completely absent. So, the purpose of this study is to diagnose the level of financial institutions preparedness for the implementation of economic security management into their common system of management. The high level of financial market participants' readiness for safe-oriented management will allow regulators to rapidly implement in their practice a list of recommendations that will minimize the threat of bankruptcy and liquidation of domestic financial institutions. Methodology. In the process of preparing a scientific article, a great number of literary sources was considered. Some of them were developed using the method of theoretical generalization and the monographic method. The theoretical results presented in the research materials were obtained on the basis of the study of works of such scientists as Amadae S. M., Baily M. N., Elliott D. J., Ismail Z., Johnson K. N., Mirtchev A., Nelson J. A., Raczkowski K., Schneider F., Sidek Z. M., Ula M., Whalen C. J., Wierzbicka E., Yong J. To confirm the reliability of the scientific results presented in the article, the authors used the Delphi method and expert evaluation. The list of indicators for assessing the level of financial institutions readiness for the implementation of a mechanism for managing economic security in the following five areas is formed. These areas are: the availability and condition of the economic security system, the state of information and analytical support for the adoption of management decisions in the field of economic security, the state of intellectual and personnel management provision of economic security, reserves of financial support of economic security, the level of external influence on the state of economic security (state regulation and supervision). In May 2018, representatives of the top management of various types of financial institutions, scientists, researchers, and analysts who were interested in the issues of economic security management of the financial sector were interviewed. Their answers were analysed and the level of readiness for managing the economic security of the most common types of financial institutions in the financial market of Ukraine was determined. Using the graphical method, the obtained scientific results are presented in a convenient and understandable form for the perception of all interested persons. Results of the survey. The necessity of carrying out diagnostics of the readiness to manage economic security at the level of state regulatory bodies and at the level of top management of financial institutions in the near future is substantiated. A large-scale analytical
\end{abstract}

\footnotetext{
Corresponding author:

${ }^{1}$ Bohdan Khmelnytsky National University of Cherkasy, Ukraine.

E-mail: natazachosova@gmail.com

${ }^{2}$ Kyiv National University of Technologies and Design, Ukraine.

E-mail: babinaamilo@gmail.com
} 
work was carried out on determining the parameters of financial institutions readiness for the continuous and professional economic security management, which should be carried out with the use of a systematic approach. Based on expert opinions, a preliminary assessment of the various types of financial intermediaries' readiness to integrate security-oriented management into the financial institutions' common management system was made. Practical implications. The proposed methodological approach for assessing the level of financial institutions readiness to manage their own economic security should be used by the state regulators of the financial market, in particular, by the National Bank of Ukraine and the National Commission, which performs state regulation in the field of financial services markets, to monitor the activities of professional financial market participants in order to conduct advisory and consultative work with their owners and managers, as well as for the development of strategic guidelines for the provision of the state financial security. It is desirable to implement into the practical activities of financial intermediaries our proposals for increasing the readiness for implementation of the economic security management mechanism in the existing systems of management. Value/originality. For the first time, a scoring methodology was prepared for assessing the level of financial institutions readiness for the implementation of economic security management as an independent direction of management, and not as one of the tasks of other types of their management activity. At the theoretical level, the substantive interpretation of the notion of the readiness of financial institutions to manage their own economic security is proposed. The reasons for the impossibility of the modern financial institutions to manage their own economic security effectively are identified, and a few suggestions to minimize their number in the near future were made.

Key words: management, economic security, financial institutions, regulation, financial market, economic security management.

\section{JEL Classification: E44, G10, G18, O16}

\section{Introduction}

The urgency of the research. The level of the national financial market development, stable and cost-effective work of its professional participants is a prerequisite for ensuring the financial security of the state. That is why the financial services markets are under constant control and supervised by state regulators who, in modern non-trivial economic and political circumstances, need a lot of new tools for diagnosing the functional characteristics of financial institutions in order to determine which of them cannot effectively perform their tasks and, consequently, posing a threat to the financial interests of clients, partners, and all other categories of stakeholders. Most financial intermediaries, who seek to continue their work in the period of post-crisis recovery of the domestic financial system, have realized the need to maintain an adequate level of their own economic security and the importance of building its integrated system. Already we can observe the development of separate functional components of the economic security system - personnel, informational, financial in banks, and rarely - in insurance companies. However, for other types of financial institutions, keeping of economic security remains, at best, like one of the strategic goals that has no tactical manifestation and resource support. In practice, the mechanism of economic security management, even if its system is formed in the common economic entities systems of management, is absent. Its tasks are performed within the framework of risk management or crisis management. The reason for this is probably of financial institutions top-management unreadiness - material, financial, organizational, etc. to the implementation of such a mechanism at the application level. However, this assumption requires empirical evidence.

Target setting. The purpose of the study is to substantiate the need of the implementation by financial institutions of a mechanism for the continuous economic security management in order to timely counter current threats to their activities in the financial market. In order to achieve this goal, it is necessary to conduct a diagnosis of the level of professional financial intermediaries' preparedness for implementing such a type of management as an independent direction of economic entities management. Taking into account the lack of tools for valuation for state regulators and top management of financial companies, the priority task of the study is to develop a methodical approach to analysing the state of preparedness of various types of domestic financial institutions for the implementation of economic security management as an independent vector of financial and economic activity management. The results of its approbation will become an important information resource for financial services markets' state regulators, owners of financial institutions and their stakeholders in the process of adopting by them various management decisions.

Actual scientific researches and issues analysis. In May 2009 , the problems of supporting the economic security of financial market participants and their clients were recognized by the scientific community and discussed in London on the Conference on Financial Institutions and Economic Security, where their vision of how to 
solve these problems presented the scientists from The Open University, UK, University of Cambridge, UK, SantAnna School of Advanced Studies, Italy, Polytechnic University of Marche, Italy, Economics Institute, Czech Republic, University of Bordeaux, France, University of Sussex, UK. Some aspects of the raised issues were found in scientific publications and analytical studies of the recent years. The great part of publications considering this topic appeared within during the period of deployment and completion of financial crises. Due to their devastating influence on the global economic system, the role and significance of the country's financial security for ensuring its national security was realized (Yong, 2009) and the need to ensure financial stability to guarantee the steady development of the economy became obvious (Whalen, 2011; Baily \& Elliott, 2013). The number of threats to the financial institutions' economic security increases from year to year; their new, non-traditional forms and types that require the development of innovative approaches to counteract them appear (Johnson, 2015; Amadae, 2017; Nelson, 2007). To prevent some of them, financial institutions needed to take comprehensive measures and to create security systems, for example, an information security system (Bank of Japan, 2000, Ula, Ismail, \& Sidek, 2011). However, the protective effect would be more prominent in the context of creating a comprehensive economic security system of the financial institution, while one of those components would become the subsystem of information security. Such a system would preserve the integrity of not only the financial assets of the institutions themselves but also guarantee the financial safety of their clients' financial assets (Wierzbicka, 2017) and the realization of their financial interests. So far, while such a system has not been created, it is expedient for financial institutions to implement a mechanism for professional and continuous management of at least those its elements that were formed under the influence of the risks for the domestic financial market functioning.

Uninvestigated parts of general matters defining. In the modern scientific literature, it is seldom possible to find the attempts to link the problem of ensuring the economic security of the business structure with the possibilities of organizations system of management (Raczkowski \& Schneider, 2013). There is also no consensus on whether state regulation contributes for establishing the state of economic security in the financial sector or, on the contrary, it hinders financial institutions in the process of their economic security self-regulation (Mirtchev, 2012). Thus, actual and timely considering in the economic realities of financial institutions professional activity in Ukraine will be a study of their readiness to start work towards the implementation of management mechanisms aimed at ensuring and maintaining an appropriate state of economic security that can be used on both micro and macro levels.

The research objective is to provide financial regulators with tools for diagnosing the financial institutions' readiness to implement economic security management and to assess its level by the end of the first half of 2018 .

Methodology. The level of financial institutions readiness to implement integrated economic security management was impossible to assess only with the help of mathematical methods because this required the availability of a significant amount of information resources and specific data that financial market participants do not disclose and categorize as commercial secrets. Therefore, one of the most authoritative expert evaluation methods was used to conduct the research - the Delfi Method. In 2015, a questionnaire for an expert survey was developed, and pilot results were obtained in 2016. In 2017, the list of questions in the questionnaire has been modified in accordance with the instructions and wishes of experts. Among them were the persons directly working in financial institutions in positions that provide them with access to comprehensive information about the state of economic security. Their authoritative opinion was taken into account when forming the second version of the questionnaire, which was used to obtain the results within the scope of this study. In 2018, a list of research objects was made for diagnosis. The experts were selected for questioning - they were the representatives of financial institutions topmanagement and their main types of stakeholders. At the end of the first half of 2018, the initiators of the survey conducted an expert survey to diagnose the level of domestic financial institutions readiness to implement economic security management and to control its status by financial market regulators, the results of which are presented in this scientific article.

The logic of material presentation. At the first stage of scientific work, the authors identified the types of financial institutions that carry out professional activities in the financial market of Ukraine and sell financial products and services to people and business. The arguments for justifying the need for managing the economic security of professional participants in the financial market are given in view according to the non-trivial and risky conditions of their current activity. The methodical peculiarities of assessing the level of financial institutions' readiness for the implementation in the practice of their economic security management are described. At the next stage of the study, the authors presented the results of assessing the level of financial institutions' readiness for managing their economic security. The study ends with the authorship proposals for improving the level of financial institutions' readiness for the professional economic security management of their own. 
2. Types of financial institutions and justification of the need for managing their economic security

The Ukrainian financial market is constantly evolving; its participants are trying to follow the tendencies of the European and world financial services markets. One of them is the constant increase in the species diversity of financial institutions, the diversification of financial products and services. The analysis of the reports of the state regulators of the financial market made it possible to identify those types of financial intermediaries, which are the most widespread in Ukraine and through which the market architecture of the domestic financial system is formed. The largest number of participants in the financial market at the beginning of 2018 is comprised of financial companies, which include both credit institutions and legal entities of public law, which changed the type of financial institution to a "financial company"; managers of real estate funds and construction financing funds, as well as administrators of financial assets for purchasing goods in groups. The second place on a quantitative basis for four years was occupied by credit unions, but at the end of 2017, this position was taken by pawnshops. Corporate and unit investment funds constitute an investment segment of the financial market, however, since they are managed by special companies - asset management companies (AMC), AMC were chosen by us for consideration within the framework of this study. The results of a retrospective analysis of the number of major types of financial institutions in the domestic market are presented in Figure 1.

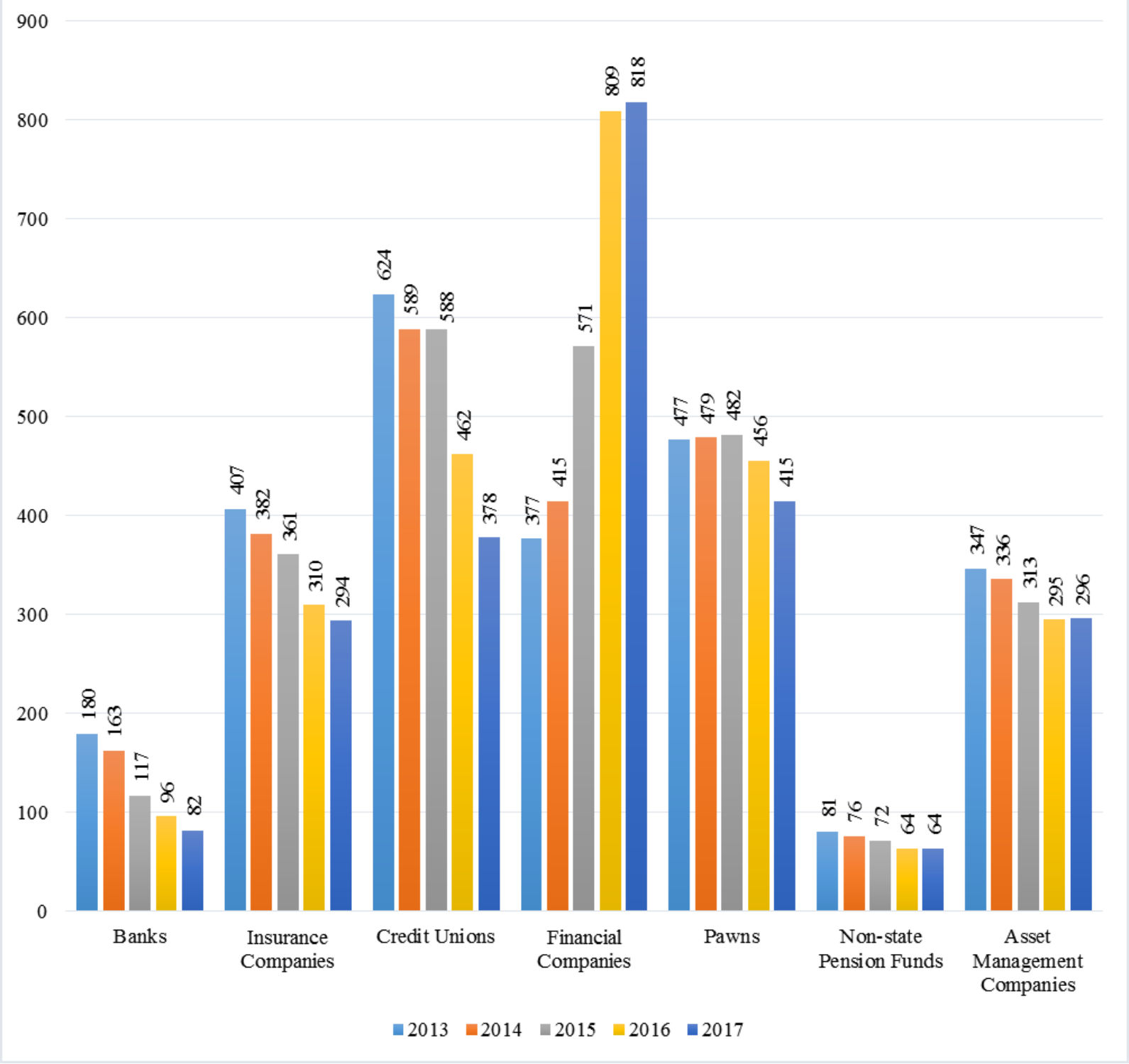

Figure 1. A number of financial institutions in the financial market of Ukraine

Source: made by the authors using data from government regulators 
There is a tendency for reducing the number of professional participants in the financial market in Ukraine. This indicates that the state of their economic security is unsatisfactory and it leads to their bankruptcy and liquidation. In banking institutions, the economic security systems have been formed, however, the dynamics of the number of banks is also negative. With this in mind, we can talk about the low efficiency of economic security systems management where the backgrounds for it are formed, and the inability to manage economic security system individual elements, where such a formation is only at the beginning stage.

Taking into account the destructive tendencies of the domestic financial market functioning, state regulators should be forced to introduce rules and norms for the economic security management. However, such actions in the conditions of low readiness of financial institutions to a new wave of regulatory requirements can further destabilize the financial market and its participants. Therefore, the authors of the article had the idea to pre-evaluate the level of financial institutions readiness to start the practice of professional economic security management and to identify the circumstances of their current state, which contribute or hinder the active implementation of this type of management in the management architecture of economic entities.

\section{Methodical peculiarities of assessing the level of financial institutions readiness to implement the practice of economic security management}

With the financial institutions readiness to implement economic security management within the scope of this study, we will understand the level of awareness and ability to guarantee the necessary management process resource provision by the part of financial institutions assets that are designed to form and operate an economic security system at all stages of its formation and development, and also the presence in the institutions' top-management of sufficient level of knowledge and skills in order to organize in the system of management a new direction of management activities aimed at protecting the institutions and their clients assets.

In order to assess the level of financial institutions' readiness for the professional economic security management and to the state regulation of this process, it is proposed to use the Delphi method. Methodological approaches to the application and aspects of the use of the Delphi method are described in scientific papers (Gorbatenko \& Petrenko, 2008; Pankratova \& Malafeeva, 2012), the recommendations of which have been applied with the use of this method in the framework of this study. The Delphi method was chosen because of its features, such as precision (the ability to work with an expert and collect data remotely) and anonymity (the possibility for the expert to not specify the institution, in which he or she works, which provides a higher level of objectivity of the assessment). In addition, to ensure the objectivity of diagnostic procedures, experts were selected among the unknown persons without direct subordination to each other. The survey was conducted extraterritorially to avoid contact between experts and to prevent the possibility of their communication.

At the first stage of the diagnosis of financial institutions' readiness for the economic security management implementation, 60 experts (of which 10 specialize in the functioning of specific types of financial intermediaries) were selected from among financial companies' managers (top management). At the second stage of the diagnosis, a questionnaire with a focused list of issues related to the processes of formation and functioning of the economic security system of financial institutions was sent to experts. At the third stage, experts corrected questionnaires in accordance with their own vision of the list of indicators for assessing the level of financial institutions readiness for the implementation of economic security management. The final version of the 2017 - sample questionnaire contained 10 questions to evaluate each of the 5 final selected groups of indicators. At the fourth stage, the experts received the final form of the questionnaire. To assess the proposed indicators, a scoring system with a 10 -point scale (10 points the best score) was offered. In case of impossibility to estimate the indicator, the expert was rated the indicator with 0 points. At the fifth stage, the processing of expertcompleted final questionnaires took place.

\section{Results of assessing the financial institutions' readiness for managing economic security}

The assessment of financial institutions' readiness for managing economic security was carried out with the 5 groups of indicators. They are:

- Group 1. Presence and state of the economic security system.

- Group 2. The state of informational and analytical support for making managerial decisions in the field of economic security.

- Group 3. Status of intellectual and personnel provision of economic security management.

- Group 4. Provisions for economic security financing.

- Group 5. Level of external influence on the economic security state (state regulation and supervision).

As already noted, each group included 10 indicators, which, according to the authors of the article, as well as experts from the world of finance, can diagnose the level of financial institutions' readiness for the implementation of economic security management into their common activity.

In Table 1, indicators are grouped according to vectors of financial institutions assessing the level of their readiness for implementing economic security management. 
Vol. 4, No. 4, 2018

Table 1

Indicators for assessing the level of financial institutions' readiness for the implementation of economic security management

\begin{tabular}{|c|c|c|c|c|c|}
\hline & 1 & 2 & 3 & 4 & 5 \\
\hline 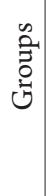 & $\begin{array}{l}\text { Presence and state of the } \\
\text { economic security system }\end{array}$ & $\begin{array}{l}\text { State of informational } \\
\text { and analytical support } \\
\text { for making managerial } \\
\text { decisions in the field of } \\
\text { economic security }\end{array}$ & $\begin{array}{c}\text { Status of intellectual } \\
\text { and personnel provision } \\
\text { of economic security } \\
\text { management }\end{array}$ & $\begin{array}{l}\text { Provisions for economic } \\
\text { security financing }\end{array}$ & $\begin{array}{l}\text { Level of external } \\
\text { influence on the } \\
\text { economic security state } \\
\text { (state regulation and } \\
\text { supervision) }\end{array}$ \\
\hline \multirow{10}{*}{ 苞 } & $\begin{array}{l}\text { Documents that } \\
\text { declare the provision of } \\
\text { economic security }\end{array}$ & $\begin{array}{l}\text { Quality of the Economic } \\
\text { Security Concept }\end{array}$ & $\begin{array}{l}\text { Correspondence of } \\
\text { education of people } \\
\text { engaged in the provision } \\
\text { of economic security to } \\
\text { the needs of this area of } \\
\text { work }\end{array}$ & $\begin{array}{l}\text { Formation of the } \\
\text { budget for financing the } \\
\text { economic security needs }\end{array}$ & $\begin{array}{l}\text { Effectiveness of the state } \\
\text { regulator of the financial } \\
\text { market }\end{array}$ \\
\hline & $\begin{array}{l}\text { Availability of the } \\
\text { economic security } \\
\text { subdivision }\end{array}$ & $\begin{array}{c}\text { Quality of the Economic } \\
\text { Security Strategy }\end{array}$ & $\begin{array}{l}\text { Level of education of the } \\
\text { staff of the institution }\end{array}$ & $\begin{array}{l}\text { Level of the salary of } \\
\text { persons involved in } \\
\text { providing economic } \\
\text { security }\end{array}$ & $\begin{array}{l}\text { Established norms of } \\
\text { economic security }\end{array}$ \\
\hline & $\begin{array}{l}\text { Frequency of economic } \\
\text { security state monitoring }\end{array}$ & $\begin{array}{l}\text { Completeness of the job } \\
\text { descriptions of persons } \\
\text { engaged in the economic } \\
\text { security provision }\end{array}$ & $\begin{array}{l}\text { Completeness of the } \\
\text { Department of Economic } \\
\text { Security with the staff }\end{array}$ & $\begin{array}{c}\text { Sufficiency of financing } \\
\text { measures for ensuring } \\
\text { economic security }\end{array}$ & $\begin{array}{l}\text { Quality of information } \\
\text { interaction with the } \\
\text { regulator }\end{array}$ \\
\hline & $\begin{array}{l}\text { Systemicity in providing } \\
\text { economic security }\end{array}$ & $\begin{array}{l}\text { Level of information } \\
\text { support department } \\
\text { organization }\end{array}$ & $\begin{array}{l}\text { Level of qualification } \\
\text { of persons involved in } \\
\text { the process of ensuring } \\
\text { economic security }\end{array}$ & $\begin{array}{l}\text { Financing of the } \\
\text { institution financial audit }\end{array}$ & $\begin{array}{l}\text { Effectiveness of state } \\
\text { supervision over } \\
\text { the activities of the } \\
\text { institution }\end{array}$ \\
\hline & $\begin{array}{c}\text { Level of counteraction to } \\
\text { external threats }\end{array}$ & $\begin{array}{l}\text { Level of the institution's } \\
\text { activities transparency }\end{array}$ & $\begin{array}{c}\text { Level of the use of } \\
\text { non-formal education } \\
\text { by the staff for its own } \\
\text { development }\end{array}$ & $\begin{array}{l}\text { Size of the sources of } \\
\text { financing the sudden } \\
\text { costs of economic } \\
\text { security measures }\end{array}$ & $\begin{array}{l}\text { Rationality of economic } \\
\text { requirements for the } \\
\text { institution }\end{array}$ \\
\hline & $\begin{array}{c}\text { Level of counteraction to } \\
\text { internal threats }\end{array}$ & $\begin{array}{l}\text { Level of paper form } \\
\text { information security }\end{array}$ & $\begin{array}{l}\text { Availability of a personnel } \\
\text { reserve for the formation } \\
\text { of a staff of experts to } \\
\text { ensure economic security }\end{array}$ & Size of the reserve fund & $\begin{array}{l}\text { Effectiveness of } \\
\text { institutions' state } \\
\text { inspections }\end{array}$ \\
\hline & $\begin{array}{c}\text { Speed of response to } \\
\text { threats }\end{array}$ & $\begin{array}{c}\text { Level of electronic } \\
\text { information security }\end{array}$ & $\begin{array}{l}\text { Level of engagement in } \\
\text { the process of ensuring } \\
\text { the economic security of } \\
\text { persons with education in } \\
\text { this kind of specialty }\end{array}$ & $\begin{array}{l}\text { Level of material support } \\
\text { of the economic security } \\
\text { subdivision }\end{array}$ & $\begin{array}{c}\text { Normative provision of } \\
\text { the economic security } \\
\text { system formation }\end{array}$ \\
\hline & $\begin{array}{l}\text { Use of external experts } \\
\text { for ensuring economic } \\
\text { security }\end{array}$ & $\begin{array}{c}\text { Level of information } \\
\text { security in the process of } \\
\text { its use }\end{array}$ & $\begin{array}{l}\text { Level of loyalty of the } \\
\text { personnel involved in } \\
\text { the process of economic } \\
\text { security provision }\end{array}$ & $\begin{array}{l}\text { Dependence of the level } \\
\text { of financing security } \\
\text { measures on the level of } \\
\text { institution profitability }\end{array}$ & $\begin{array}{c}\text { Regulators information } \\
\text { support on economic } \\
\text { security issues }\end{array}$ \\
\hline & $\begin{array}{l}\text { Institution financial } \\
\text { performance }\end{array}$ & $\begin{array}{l}\text { Completeness of } \\
\text { information for assessing } \\
\text { the institutions level of } \\
\text { economic security }\end{array}$ & $\begin{array}{l}\text { Personnel fluidity in the } \\
\text { institution }\end{array}$ & $\begin{array}{l}\text { Existence of a } \\
\text { compensation fund for } \\
\text { covering losses from the } \\
\text { threats to the institution } \\
\text { financial state }\end{array}$ & $\begin{array}{l}\text { Preparation of financial } \\
\text { institutions ratings } \\
\text { (including the parameter } \\
\text { of economic security) }\end{array}$ \\
\hline & $\begin{array}{c}\text { Level of economic } \\
\text { security of the institution }\end{array}$ & $\begin{array}{l}\text { Number of sources } \\
\text { for obtaining data to } \\
\text { organize the institutions' } \\
\text { resource protection }\end{array}$ & $\begin{array}{l}\text { Persons involved in the } \\
\text { process of economic } \\
\text { security provision } \\
\text { working experience } \\
\text { precisely in this area }\end{array}$ & $\begin{array}{c}\text { Availability of financial } \\
\text { guarantees for institution } \\
\text { clients }\end{array}$ & $\begin{array}{c}\text { State audit of economic } \\
\text { security }\end{array}$ \\
\hline
\end{tabular}


Table 2

Results of assessing the state of financial institutions' readiness for the implementation of economic security management

\begin{tabular}{|c|c|c|c|c|c|}
\hline \multirow[b]{2}{*}{$\begin{array}{l}\text { Type of financial } \\
\text { institution }\end{array}$} & \multicolumn{5}{|c|}{ Average score } \\
\hline & $\begin{array}{c}\text { Presence and } \\
\text { state of the } \\
\text { economic } \\
\text { security system }\end{array}$ & $\begin{array}{l}\text { The state of } \\
\text { informational and } \\
\text { analytical support for } \\
\text { making managerial } \\
\text { decisions in the field of } \\
\text { economic security }\end{array}$ & $\begin{array}{c}\text { Status of the } \\
\text { intellectual and } \\
\text { personnel provision } \\
\text { of economic security } \\
\text { management }\end{array}$ & $\begin{array}{c}\text { Provisions } \\
\text { for economic } \\
\text { security financing }\end{array}$ & $\begin{array}{l}\text { Level of external } \\
\text { influence on the } \\
\text { economic security state } \\
\text { (state regulation and } \\
\text { supervision) }\end{array}$ \\
\hline Banks & 7 & 8 & 8 & 8 & 9 \\
\hline Insurance companies & 5 & 5 & 6 & 7 & 8 \\
\hline Credit unions & 3 & 3 & 5 & 3 & 7 \\
\hline $\begin{array}{l}\text { Investment Companies } \\
\text { (NPF and AMC) }\end{array}$ & 6 & 5 & 5 & 5 & 7 \\
\hline Pawns & 5 & 4 & 2 & 2 & 6 \\
\hline Financial companies & 6 & 4 & 4 & 5 & 7 \\
\hline
\end{tabular}

In Table 2, the average values of experts' point scores obtained as a result of the diagnosis of the financial institutions' readiness for the implementation of the economic security management process are presented.

As an integral indicator of the level of financial institutions' readiness for the implementation of economic security management as a separate management direction, it is proposed to apply the relative area of the radar $(\mathrm{Sr})$ constructed in the middle of the circle for several indicators (Formula 1):

$$
S r=\frac{S p}{S}(1)
$$

where $\mathrm{Sp}$ - radar area, $\mathrm{cm}^{2}$;

$S$ - the total area of the estimated circle, is equal to $\pi \cdot R^{2}$;

$\mathrm{R}$ - arbitrary radius of the estimated circle, $\mathrm{cm}$.

In order to obtain more accurate data for indicators based on the results of the study, the radar is built on the basis of the following assumptions:
- all indicators have the same weight; the circle is divided into 5 equal sectors, the angle between which is $72^{\circ}$;

- indicators are stimulants (increasing their values positively affects the state of financial institutions readiness to implement the economic security management), therefore, as they move away from the centre of the circle, their values are improved.

The radar area $\mathrm{Sr}$ is determined by the formula:

$$
S r=1 / 2 \sin \alpha\left(\alpha_{1} \cdot \alpha_{2}+\alpha_{2} \cdot \alpha_{3}+\alpha_{n} \cdot \alpha_{1}\right)
$$

where $\alpha_{1} ; \alpha_{2} ; \alpha_{n}$ - values of the indicators translated into centimetres (we accept 1 point $=1 \mathrm{~cm}$ );

$\alpha$ - the angle between the nearest indicators, we accept $\alpha=72^{\circ}$.

Based on the given data, we will determine the level of financial institutions' readiness for the implementation of economic security management:

Banks: $\operatorname{Sr} 1=1 / 2 \sin 72^{\circ}(7 \cdot 8+8 \cdot 8+8 \cdot 8+8 \cdot 9+9 \cdot 7)=1 / 2 \cdot 0,951 \cdot 319=151,68 \mathrm{~cm}^{2}$

Insurance companies: $\operatorname{Sr} 2=1 / 2 \sin 72^{\circ}(5 \cdot 5+5 \cdot 6+6 \cdot 7+7 \cdot 8+8 \cdot 5)=1 / 2 \cdot 0,951 \cdot 193=91,77 \mathrm{~cm}^{2}$

Credit unions: $\operatorname{Sr} 3=1 / 2 \sin 72^{\circ}(3 \cdot 3+3 \cdot 5+5 \cdot 3+3 \cdot 7+7 \cdot 3)=1 / 2 \cdot 0,951 \cdot 81=38,52 \mathrm{~cm}^{2}$

Investment companies (NPF and AMC):

$\operatorname{Sr} 4=1 / 2 \sin 72^{\circ}(6 \cdot 5+5 \cdot 5+5 \cdot 5+5 \cdot 7+7 \cdot 6)=1 / 2 \cdot 0,951 \cdot 157=74,65 \mathrm{~cm}^{2}$

Pawns: $\operatorname{Sr} 5=1 / 2 \sin 72^{\circ}(5 \cdot 4+4 \cdot 2+2 \cdot 2+2 \cdot 6+6 \cdot 5)=1 / 2 \cdot 0,951 \cdot 74=35,19 \mathrm{~cm}^{2}$

Financial companies: $\operatorname{Sr} 6=1 / 2 \sin 72^{\circ}(6 \cdot 4+4 \cdot 4+4 \cdot 5+5 \cdot 7+7 \cdot 6)=1 / 2 \cdot 0,951 \cdot 137=65,14 \mathrm{~cm}^{2}$

Integral indicator (I) for estimation the level of financial institutions' readiness to implement the economic security system management is:

For banks: $I_{1}=151,68 /\left(3,14 \times 10^{2}\right)=0,483$.

For insurance companies: $I_{2}=91,77 /\left(3,14 \times 10^{2}\right)=0,292$.

For credit unions: $I_{3}=38,52 /\left(3,14 \times 10^{2}\right)=0,123$.

For investment companies (NPF and AMC): $\mathrm{I}_{4}=74,65 /\left(3,14 \times 10^{2}\right)=0,238$.

For pawns: $I_{5}=35,19 /\left(3,14 \times 10^{2}\right)=0,112$.
For financial companies: $I_{6}=65,14 /\left(3,14 \times 10^{2}\right)=0,207$.

The value of integral indicators of financial institution readiness for the implementation of economic security management is shown in Figure 2.

According to the calculations carried out, we conclude that the pawnshops are the least ready to implement economic security management in their common management system. A slightly better state of the readiness is in credit unions. However, both these types 


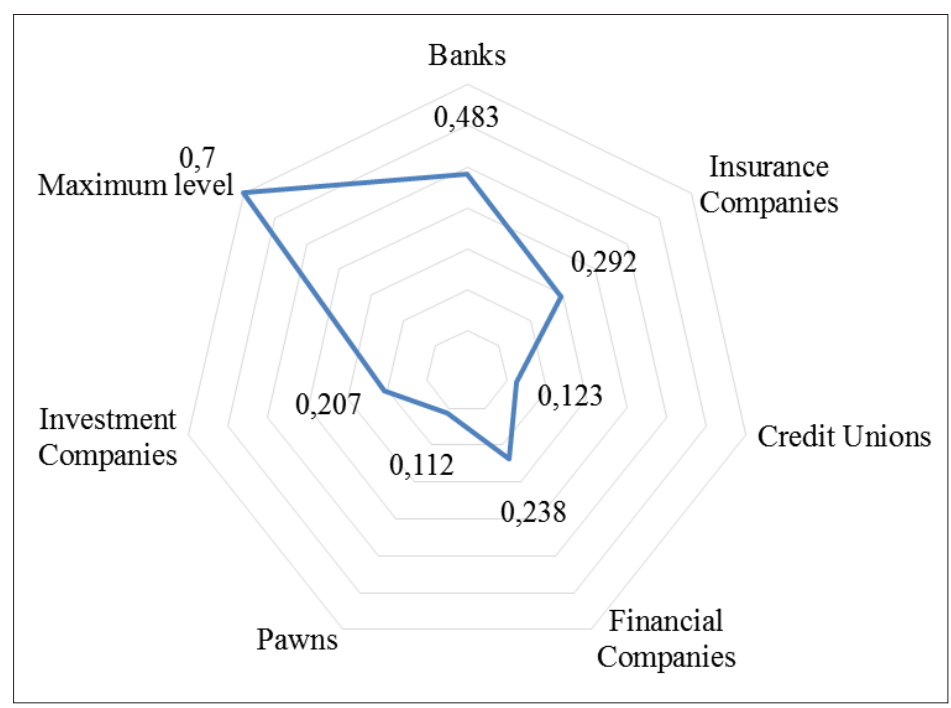

Figure 2. Integral indicators of financial institutions readiness

for the economic security management implementation of mid-2018

of financial institutions are not, at the moment, able to allocate an adequate amount of resources for managing economic security system, which, in addition, is in the embryonic state of formation. Thus, the activity of pawnshops and credit unions requires the more active interference of state regulators since independently these financial institutions are not able to provide their own economic security and are not able to guarantee the realization of financial interests for their clients.

\section{Reasons for the low level of financial institutions' readiness for the economic security professional management realization}

As a result of the research and development of filled by experts questionnaires, surveys, and analysis of the current state of the financial market, we were able to identify the reasons for the low level of financial institutions readiness for the professional management of their economic security. For banks, the level of informational, analytical, intellectual, and personnel support of this process remains the problematic aspects of the readiness for implementation of the economic security management. During the expert evaluation, the lowest points in the diagnosis of these indicators were assigned in the information plane - for the state of the Economic Security Concept and Strategy formation. Based on data obtained from experts, it can be concluded that these two documents are not currently available in banks, or their development has just begun. As for the intellectual and personnel security, the lowest estimates of experts were obtained due to the need to attract external specialists to protect the resources of the institution, which, however, $50 \%$ of banks do not consider seriously, and also because of the lack of practice of raising the level of skills of staff involved in ensuring economic security.
For insurance companies, the state of their economic security systems, the level of informational, analytical, intellectual, and human resources provision of economic security remain problematic aspects. Expert opinions suggest that $40 \%$ of insurance companies have not completely formed economic security system, whose functional level would allow the implementation of a mechanism for their economic security management. The reasons for this is the low level of the department of economic security organization (or the absence of such a unit) and the lack of economic security level monitoring (the mechanisms for economic security state monitoring, that was achieved by insurance companies in the process of their functioning).

The indicator of the state of insurance companies preparedness for the implementation of the economic security management is substantially lower, as is the case with the banks, the economic security Concept and Strategy are absent, as well as the unsatisfactory level of departments of information provision staffing with the specialists of proper qualification is present. In addition, insurance companies, according to experts, feel the lack of methodological approaches and information resources for assessing the level of economic security. The negative assessment was received because of the rare facts of the participation of persons engaged in the provision of economic security in seminars and trainings. That does not contribute to raising their level of knowledge, skills, and competencies, as well as the level of involvement into the organization of institutions resources protection only a few persons with academic degrees.

The lowest assessments of the credit unions readiness to manage economic security were put by experts because of the lack of strategic and tactical planning of protective measures; information gaps in the job 
descriptions of persons involved in the provision of economic security; insufficient level of staffing of the departments of information support, lack of sources of information provision of management decisions in the area of economic security. Also, there is a low frequency of people involved in the provision of economic security participation in seminars and trainings.

It should be noted that the state of preparedness of investment institutions for the implementation of economic security management is better than the state of credit unions, however, comparing to banks and insurance companies, investment companies are lagging behind. The reasons for reducing their readiness assessment are the same as that of banks and insurers - the lack of conceptual and strategic principles for ensuring economic security, the lack of a documentary basis for assessing the level of economic security of the institution. Companies need to attract external specialists to protect the resources of the institution because their own personnel potential is not enough for that.

There are problems in the level of state regulation of the state of economic security of investment companies. Thus, experts note the fact that the instructions on ensuring economic security and even some of its parameters are not elaborated. There is a lack of state audit mechanisms for the economic security level checking.

Pawnshops are the outsiders among financial institutions in terms of readiness for the economic security management implementation. Typical problems noted by experts in the process of assessing pawnshops are: the complete absence of documentary evidence of the economic security system functioning, the low level of the institutions' transparency, the absence of the budget to ensure economic security. Parameters that received a low rating when assessing the level of readiness of other types of financial institutions, in particular, within the framework of informational, analytical, intellectual, and personnel provision of the economic security system, are also characteristic for pawnshops.

\section{Proposals for improving the state of financial institutions readiness for professional economic security management}

Thus, there is an urgent need to find reserves for improving the readiness of financial institutions' of all segments of the financial market - in the banking sector, in the insurance sector, in the sector of investment institutions, in the sector of credit co-operation, and in the sector of financial companies - for the implementation of the economic security management as an independent direction of the company management by:

- development and use of methodological tools for assessing the financial institutions' economic security level in order to obtain relevant information resources for decisions in the field of economic security management;
- establishment of standards of economic security by the state regulator and permanent monitoring of the level of their compliance with financial institutions activities;

- formation of special funds for financing measures to counter threats to the financial institutions' economic security;

- conduction of an explanatory work about the principles and tasks of economic security providing;

- establishment of units for ensuring economic security or appointment of persons responsible for the economic security state in the staff structure of financial institutions, etc.

We believe that in the short term, increasing the readiness of financial institutions for the implementation of economic security management is possible by defining strategic and tactical priorities for making managerial decisions regarding the protection of financial institutions and their clients' assets from external and internal threats impact.

Taking into account the financial market development trends, in which domestic financial institutions operate, the following list of tactical priorities for managing their economic security can be proposed in order to increase their readiness to implement a holistic mechanism for such management:

- the election as the priority the state of financial and information security, the transfer of available free financial resources for their protection;

- for certain types of financial institutions such as credit unions and pawnshops, it is expedient to transfer the function of economic security management to external companies that specialize in organizing the protection of company assets against all kinds of threats;

- the rejection of the practice of compensating losses from the threats to the economic security of financial institutions, accept the model of preventing them; - the organization of close cooperation both between financial institutions of one type and between professional participants of different segments of the financial market and representatives of state regulators of financial services markets for the purpose of forming a single database of clients who have committed fraudulent actions to financial institutions, as well as a single database of employees who mistreated their obligations that have damaged the financial status of the institution or its business reputation;

- the development of documentation that would regulate the relations between the entities providing economic security of financial institutions, both external and internal; would clearly outline the purpose, tasks, and directions of maintaining an adequate level of economic security and would establish liability for noncompliance with its norms;

- the start of periodic monitoring of the level of financial institutions economic security by their top management, owners and other categories of stakeholders. 
Thus, the emphasis in the economic security management of financial institutions on concrete and achievable goals will ensure a high level of readiness of financial institutions for the professional and permanent implementation of this area of management activities into the overall system of business entity management.

\section{Conclusions}

The results of the study show that financial institutions' top-management does not pay enough attention to ensuring the economic security of both companies and their clients' assets. The reason for this is the lack of financial resources for the organization of proper protection, lack of documentation for coordinating actions on ensuring economic security, low level of staff training for security-oriented management, etc. In view of this, we consider that it is necessary to establish, at the state level, mandatory standards of economic security, the observance of which in financial institutions should be controlled by financial market regulators. Their introduction will automatically force financial market participants to begin the process of economic security management, looking for reserves to optimize its position, which will positively affect the development of the domestic financial market and the level of financial security of the state. The value of the research is in the possibility of using its results as an information resource for the adoption by government agencies, owners, and managers of financial institutions' different types of management decisions. The methodological approach proposed in the article can be used as one of the tools for diagnosing the state of the domestic financial market and its participants of readiness to convergence with the markets of financial services of European states.

\section{References:}

(2000) The Importance of Information Security for Financial Institutions and Proposed Countermeasures. Bank of Japan, April 18, 23 p.

Amadae, S. M. (2017). Perpetual Anarchy: From Economic Security to Financial Insecurity. Finance and Society, no. 3(2), pp. 188-196.

Baily, M. N. \& Elliott, D. J. (2013). The Role of Finance in the Economy: Implications for Structural Reform of the Financial Sector. The Brookings Institution, July 11, 34 p.

Gorbatenko, V. \& Petrenko, I. (2008). Metod «Delfi» ta spetsyfika yoho zastosuvannya u prohnoznykh rozrobkakh [The «Delphi» method and the specifics of its application in forecast developments] Political Management, no. 6 , pp. 174-182.

Johnson, K. N. (2015). Cyber Risks: Emerging Risk Management Concerns for Financial Institutions. Georgia law review, vol. 50:131, pp. 132-142.

Mirtchev, A. (2012). Will Financial Regulation Trash Global Economic Security? Investing. Retrieved from: https://www.forbes.com/sites/investor/2012/03/29/will-financial-regulation-trash-global-economicsecurity/2/\# (accessed 25 June 2018)

Nelson, J. A. (2007). Information Security Risk in Financial Institutions. International Journal of Economics and Management Engineering, vol. 1, no. 10, pp. 528-530.

Pankratova, N. D. \& Malafeeva, L. Yu. (2012). Formalyzatsyya sohlasovanyya ekspertnykh otsenok pry realyzatsyy metoda Delfy [Formalization of the coordination of expert assessments in the implementation of the Delfi method] Cybernetics and System Analysis, no. 5, T. 48, pp. 82-94.

Raczkowski, K. \& Schneider, F. (2013). The Economic Security of Business Transactions: Management in Business, Oxford, Chartridge Books Oxford, $448 \mathrm{p}$.

Ula, M., Ismail, Z. bt \& Sidek, Z. M. (2011). A Framework for the Governance of Information Security in Banking System. Journal of Information Assurance \& Cybersecurity, Vol. 2011, Article ID 726196, 12 p.

Whalen, C. J. (2011). Financial Instability and Economic Security After the Great Recession, Edward Elgar Publishing Limited, UK, 223 p.

Wierzbicka, E. (2017). Dilemmas of Financial Consumer Security. Journal of Insurance, Financial Markets and Consumer Protection, no. 26 (4/2017), pp. 31-46.

Yong, J. (2009). Financial Security is at the Heart of National Economic Security. English Edition of Qiushi Journal, vol. 1, no 1. Retrieved from: http://english.qstheory.cn/magazine/200901/201109/t20110919_111216.htm (accessed 25 June 2018)

Natsionalna komisiya, shcho zdiysnyuye derzhavne rehulyuvannya u sferi rynkiv finansovykh posluh (2017). Richni zvity Natskomfinposluh [Annual reports of the National Financial Services Commission]. Retrieved from: https://www.nfp.gov.ua/ua/Richni-zvity-Natskomfinposluh.html (accessed 25 June 2018)

Natsionalnyy bank Ukrayiny (2018). Pokaznyky bankivskoyi systemy [Indicators of the banking system]. Retrieved from: https://bank.gov.ua/control/uk/publish/article?art_id=34661442\&cat_id=34798593 (accessed 27 April 2018)

Ukrayinska asotsiatsiya investytsiynoho biznesu (2018). Osnovni tsyfry [Basic figures]. Retrieved from: http://www.uaib.com.ua (accessed 25 June 2018) 